\title{
Geographically Weighted Regression Model for Poverty Analysis in Jambi Province
}

\author{
Inti Pertiwi Nashwari, Ernan Rustiadi, Hermanto Siregar, and Bambang Juanda
}

Received: 08042016 / Accepted: 2408 2016 / Published online: 30062017

(c) 2017 Faculty of Geography UGM and The Indonesian Geographers Association

\begin{abstract}
Agriculture sector has an important contribution to food security in Indonesia, but it also huge contribution to the number of poverty, especially in rural area. Studies using a global model might not be sufficient to pinpoint the factors having most impact on poverty due to spatial differences. Therefore, a Geographically Weighted Regression (GWR) was used to analyze the factors influencing the poverty among food crops famers. Jambi Province is selected because have high number of poverty in rural area and the lowest farmer exchange term in Indonesia. The GWR was better than the global model, based on high value of R2, lowers AIC and MSE and Leung test. Location in upland area and road system had more influence to the poverty in the western-southern. Rainfall was significantly influence in eastern. The effect of each factor, however, was not generic, since the parameter estimate might have a positive or negative value.
\end{abstract}

Keywords: food crop farmer, Geographically Weighted Regression, poverty, spatial analysis

\begin{abstract}
Abstrak Sektor pertanian memiliki peran penting terhadap ketahanan pangan di Indonesia, tetapi juga memberi pengaruh pada angka kemiskinan khususnya di wilayah pedesaan. Penelitian dengan menggunakan model global kemungkinan tidak sesuai lagi untuk mengetahui faktor-faktor yang mempengaruhi kemiskinan berdasarkan karakteristik spasial. Oleh karena itu, penelitian ini menggunakan metode Geographically Weighted Regression (GWR) untuk menganalisis faktor yang mempengaruhi kemiskinan petani tanaman pangan. Propinsi Jambi digunakan sebagai lokasi penelitian karena wilayah ini memiliki kemiskinan di pedesaan yang tinggi dan Nilai Tukar Petani (NTP) yang paling rendah di Indonesia. GWR memberikan hasil yang lebih baik dibandingkan model global berdasarkan nilai R2 yang tinggi, nilai AIC dan MSE yang kecil, dan uji Leung. Wilayah lereng/gunung dan jaringan jalan lebih signifikan terhadap kemiskinan di wilayah barat-selatan Jambi. Curah hujan signifikan di wilayah timur. Pengaruh setiap faktor tidak sama di setiap lokasi, karena estimasi parameter dapat positif atau negatif.
\end{abstract}

Kata kunci: analisis spasial, Geographically Weighted Regression, kemiskinan, petani tanaman pangan

\section{Introduction}

The Asian Development Bank [ADB, 2009] reported that 82 percent of poor workers lived in rural area. Of all poor workers in rural area, 66 percent worked in non-formal agricultural sector and the remaining 46 percent worked in formal sector. Although agriculture sector plays an important role in maintaining supply for food and industrial sectors and therefore contributes to food security, the growth of agricultural sector is stagnant and is lagging behind the growth of nonagricultural sector. It is then not surprising when the poverty in rural area increased from 13.76 percent in September 2014 to 14.09 percent in September 2015 [BPS, 2016]. Moreover, the agriculture sector still contributed to the high number of poverty in rural area as indicated by the high number of poor rural area's residents, who depended on the agricultural sector.

Poverty in Indonesia has been widely studied [Lisanty and Tokuda, 2015; Sudarlan et al., 2015;

\footnotetext{
Inti Pertiwi Nashwari, Ernan Rustiadi, Hermanto Siregar, and Bambang Juanda

Department of Regional and Rural Development Planning Science, Bogor Agricultural University

Correspondent email: pertiwiinti@gmail.com
}

Sudaryanto, 2009; Sumarto and de Silva, 2013; Suryahadi and Hadiwidjaja, 2011; Teguh and Nurkholis, 2011; Warr, 2013; Yosnofrizal, 2011] to pinpoint the factors affecting poverty. However, the poverty analysis in Indonesia was previously based on the global approach, which might not be suitable considering the different typology and geographical locations of Indonesian islands. In other countries, the spatial approach was already applied for poverty analysis [Yamauchi et al., 2010; Smajgl and Bohensky, 2013]. Although the spatial approach was already known in Indonesia, it was used for other purposes than poverty analysis [Saefuddin, et al., 2011; Bekti and Sutikno, 2011; Saefuddin, et al., 2012]. Using different spatial approach, Jajang [2014] used a dynamic spatial panel model and Pasaribu [2015] used a Spatial Lag Model (SLM), Spatial Error Model (SEM) and Spatial Autoregressive Moving Average (SARMA) to analyze poverty in Indonesia.

The spatial approach does not relate only to distance, location and situation, access, correlation and pattern [Muta'ali, 2012], but also to spatial pattern, correlation between variables, and spatial process. Most of the poverty cases in Indonesia are spatially concentrated. They are often found in remote area, 
characterized by having poor access and are located in difficult geographical location [Minot et al., 2006]. Moreover, the spatial econometrics has a correlation with regional cases and rural economic, which are based on biological and geological phenomenon, and regional science [Anselin, 1988]. A previous study [World Bank, 2007] suggested that geographical location has correlation with poverty. Therefore, an analysis using geographical disaggregation technique at the lowest level of governmental structure is needed to replace the macro approach for poverty analysis in Indonesia.

In this study, the global and spatial approaches were compared and the most factors influencing poverty were suggested. Three different factors, namely road system (asphalt/concrete road), location in upland area (mountain top/slope) and the amount of rainfall, are selected for the independent variables to explain the poverty cases in rural area. Different characteristics of each location, such as access to market or inner area, typology and climate, have impact on the poverty of food crops farmer. The upland area, which is located far and has poor accessibility to inner area, might have a high number of poverty cases; while the area with high amount of rainfall is expected to have a low number of poverty cases.

Jambi province, which is located in Sumatera Island, was used as a model for the poverty analysis using the global and spatial approach. Jambi province was selected not only because of it has high poverty cases among food crops farmers, but also has the lowest value of farmer exchange term/Nilai Tukar Petani (NTP) in Sumatera Island. The result of this study can be used as a basis to formulate strategies for poverty alleviation in Jambi province.

\section{The Methods}

The data obtained from 131 sub-districts in Jambi province (Figure 1) was used in current study. The independent variables used to analyze the factors influence farmer poverty in food crops subsector were road system, location in upland area (mountain top/ slope) and rainfall, while the dependent variable was the percentage of poor food crops farmer (Table 1). The data for dependent variable was obtained from "Pendataan Program Perlindungan Sosial"(PPLS) [BPS, 2011] and the data for independent variable was extracted from Agriculture census [BPS, 2013], the potency of rural area [BPS, 2015] and the data obtained from climatology station of Jambi Province Global regression analysis [Hill, et al., 2011; Gujarati, 2010] (Equation 1) and Geographically Weighted Regression (GWR) (Equation 2) were used to analyze the factor(s) affecting farmer's poverty in food crops sub-sector. The GWR model is the weighted global regression model [Fotheringham, et al., 2002, Fischer and Getis, 2010]. In this model, the model parameters are estimated for each geographical coordinate, and therefore each coordinate has different regression parameter estimates. In comparison to OLS or global regression analysis, the GWR model was reported as more suitable for data description [Ali, et al., 2007].

$$
y_{i}=\beta_{0}+\sum_{k=1}^{p} \beta_{k} x_{k}+\varepsilon_{i}
$$

Where yi is dependent variable at $\mathrm{i}$ location $(\mathrm{i}=1,2, . ., \mathrm{n})$, xik is independent variable $\mathrm{k}$ at $\mathrm{i}$ location (Table 1), $\beta$ is the regression coefficient and $i$ is the error assumed as identical, independent and has normal distribution with constant variance $\left(a_{2}\right)$. The assumption was tested by Kolmogorov Smirnov method for normal distribution, Glejser method for identical, and Durbin Watson method for independent. The parameters were estimated using the Ordinary Least Square (OLS) method. The GWR model is (2)

Table 1. Independent variable

\begin{tabular}{ll}
\hline \multicolumn{1}{c}{ Variables } & \multicolumn{1}{c}{ Definition } \\
\hline $\begin{array}{l}\text { Road system (Asphalt/con- } \\
\text { crete road (X1)) }\end{array}$ & $\begin{array}{l}\text { The percentage of rural area } \\
\text { based on the type of road } \\
\text { surface of asphalt/concrete. } \\
\text { The road connects between } \\
\text { production center/ agricul- } \\
\text { tural land to the main road of } \\
\text { rural area. }\end{array}$ \\
& $\begin{array}{l}\text { The percentage of rural area } \\
\text { located in slope or mountain } \\
\text { top. }\end{array}$ \\
(mountain top/slope area & The average of annual rainfall \\
(X2)) & (mm) \\
Rainfall (X3) & \\
\hline
\end{tabular}




$$
y_{i}=\beta_{0}\left(u_{i}, v_{i}\right)+\sum_{k=1}^{p} \beta_{k}\left(u_{i}, v_{i}\right) x_{k}+\varepsilon_{i}
$$

Where (ui,vi) are the longitude and latitude coordinates at $\mathrm{i}$ location in certain geographical region, $\beta \mathrm{k}$ (ui,vi) is the regression coefficient $\mathrm{k}$ in each region or the manifestation of the continuous function of $\beta \mathrm{k}$ (ui, vi) at i location. The parameters $\beta$ were estimated by Weighted Least Square (WLS) (Equation 3).

$$
\hat{\mathbf{a}}(i)=\left(\mathbf{X}^{T} \mathbf{W}(i) \mathbf{X}\right)^{-1} \mathbf{X}^{T} \mathbf{W}(i) \mathbf{y}
$$

Where $\mathrm{X}$ is the independent variable matrix, $\mathrm{W}(\mathrm{i})$ is the weighted matrix, and $y$ is the vector of dependent variable. GWR require the weighted matrix which shows about neighboring among locations. The type of weighting matrix was kernel bi-square (Equation 4).

$$
w_{j}\left(a_{i}, v_{i}\right)= \begin{cases}{\left[1-\left(d_{j} / b\right)^{2}\right]^{2}} & , f d_{j}<b \\ 0 & , f d_{j} \geq b\end{cases}
$$

Where wj(ui,vi) is the weighted among location $i$ in coordinate (ui,vi) and other location, dij is Euclidean distanceiand jlocation, and b is bandwidth. Bandwidth is measure the distance weighting function and the extent of influence the location to another location. Bandwidth is calculated based from Cross Validation (Equation 5),

$\mathbb{C}=\sum_{i=1}^{n}\left[y_{i}-\hat{y}_{\neq i}(b)\right]^{2}$
Where $\left\lfloor y_{i}-\hat{y}_{\neq i}(b)\right\rfloor$ the predicted is value from model without observation i. Identification of spatial effect is also important to know that the data is more relevant to analyzed by spatial model, especially for GWR. The methods are Moran's test, Local Indicator of Spatial Autocorrelation (LISA) for test of spatial independency and BreuschPagan test for spatial heterogeneity. Moran's I and LISA used to determine whether there is a spatial dependency among locations with the null hypothesis is there is no spatial dependencies. Breusch-Pagan uses the null hypothesis that there is no spatial heterogeneity in the model. The models were run using R Software. It needs a spgwr and spdep package.

\section{Result and Discussion}

The number of poor people in rural area of Jambi province was higher than in urban area. The book of poverty data and information [BPS, 2013] revealed that around 39 percent (from 2.318.485 people) of the poor people aged above 15 years worked in agricultural sector. In 2012, around 14.33 percent of 63.529 people total agricultural workers were poor people aged above 15 years old and worked in food crops subsector. The agricultural sector in Jambi province was dominated by the subsectors of plantation and food crops. However, the food crops subsector has also been considered as one of the contributors of poverty cases, as can be seen from the high number of poor people worked in food crops subsector [BPS, 2013]. Some food crops households experience what is called as multi-dimensional poverty. BPS [2014] mentioned that there was 27.41 percent (5) households in food crops subsector which experience

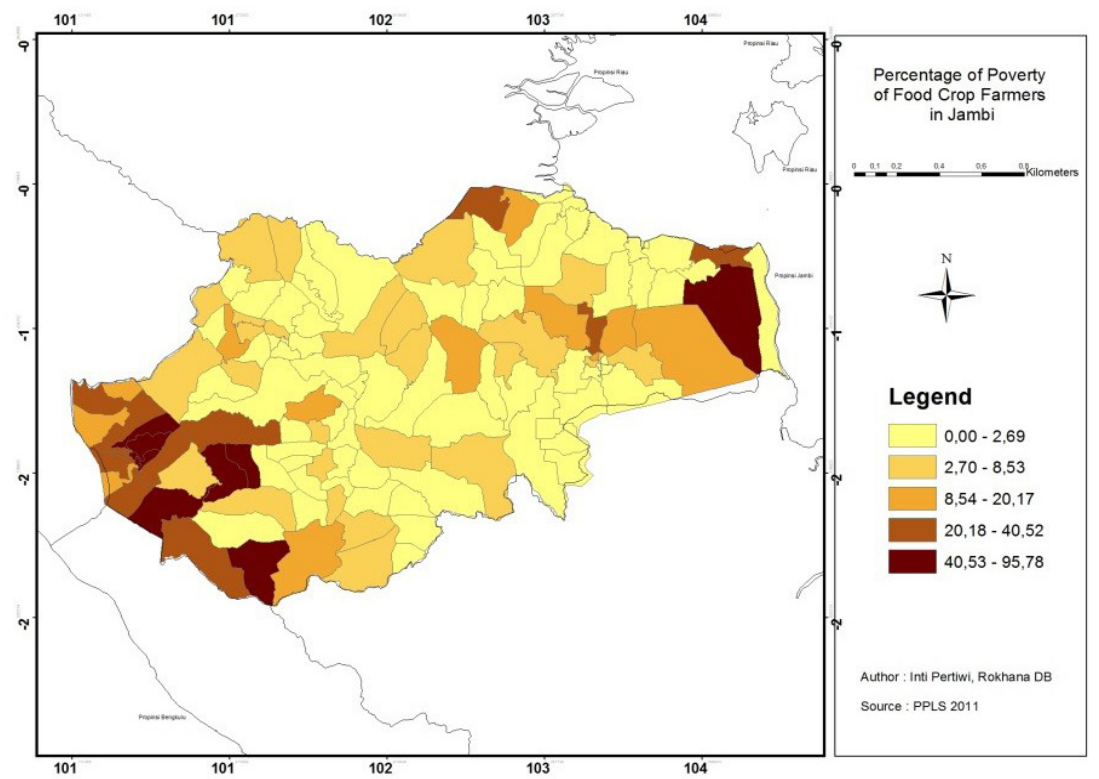

Figure 2. The percentage of poor food crops farmer household in Jambi province (PPLS, 2011). 
on multidimensional poverty in 2013. This value was calculated from Multidimensional Poverty Index (MPI) which shows the composite index. It measure poverty more broadly, especially in the case of limited access to education, healthy, and quality of live. The food crops farmer household had a lower income as compared to the other type of farmer households, indicating that the welfare of food crops farmer household was also still low. Of all provinces in Sumatera Island and even in Indonesia, Jambi province had the lowest farmer's term of trade or Nilai Tukar Petani (NTP) in 2013 [BPS, 2015]. In addition, the agricultural land owned by this type of farmer household also decreased from $1,028.41 \mathrm{~m} 2$ in 2003 to $963.16 \mathrm{~m} 2$ in 2013 [BPS, 2013], reducing the amount of crops and finally the total income received by food crops farmer. The percentage of poor food crops farmer households in Jambi province is presented in Figure 2. Most of the poor households were found in Merangin and Kerinci regencies and in the eastern part of Jambi province, such as in Tanjung Jabung Timur Regency. The distance to the regency capital seemed to have a correlation with poverty. For example, the sub-districts having the highest number of poor household, such as Sungai Tenang, Sungai Manau, and Pangkalan Jambu, are located far from Bangko, the capital of Merangin Regency. The centre of growth is a geographical location for all activities, including economic activities [Cappelo, 2007]. Therefore, the area, which are located far from the centre of growth (capital area) and has low accessibility to good infrastructure facility, might be less developed and has more poor inhabitant than area close to the centre of growth and/or with good infrastructure facility.

The poverty characteristic as function of road system, location in upland area and the amount of rainfall in each sub-district in Jambi Province varied (Figure 3). The secondary data collected from BPS [2015] showed that less than 50 percent of villages in sub-districs with high percentage of poor households had access to asphalt/concrete road from production centre to the centre of the village, confirming the connection between poverty and road system. However, interestingly high number of poor household was also found in sub-districts with good infrastructure facilities. In this case, the transport system, which connects a sub-district with other sub-districts or regencies, is lacking and the good road access was meant for other purposes, such as access for forest industry rather than for agriculture. Similarly to road system, location in upland area also contributed to the high number of poverty. A high number of poor households was found in upland area (mountain top/slope), but some were also found in lowland area, where the access to road system is considered better than in upland area. The
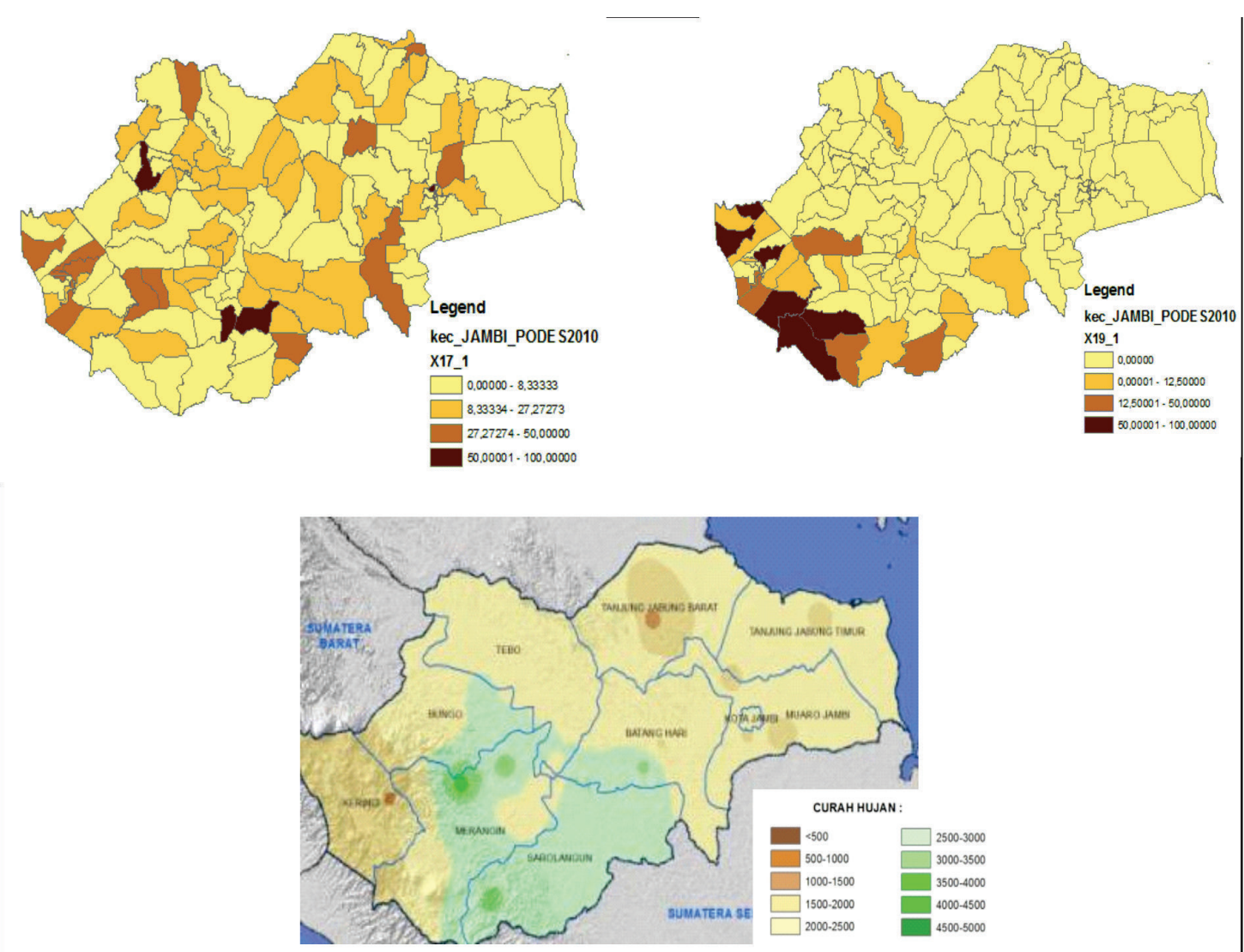

Figure 3.The poverty Characteristic as Function of (a) Road System/ Infrastructure, (b) Location in Upland Area, (c) the Amount of Rainfall 
distance to the center of growth might be the reason for the high poverty rate in lowland area since most of the poor households in lowland area live near the shoreline/coastal area. Moreover, low poverty rate was found in the area with high amount of rainfall per year, which might be correlated to the high amount of yields. However as road system and location in upland area, the effect of rainfall on the number of poverty was not conclusive since high poverty rate was also found in the area having high amount of rainfall per year. Although having a high amount of rainfall per year, this area might be located in upland area, far from the center of economic or having poor access to the road system, which influence their access to the center of growth.

The result of the global regression model is presented in Table 2. The global regression model assumed that the parameters for all sub-districts are similar, indicating that the factors influencing poverty in all sub-districts was also similar.

The regression coefficient in Table 2 was used in the global regression model in equation 1, resulting in $\hat{\mathrm{Y}}=13.560+0.150 \mathrm{X} 1+0.324 \mathrm{X} 2-3.062 \mathrm{X} 3$. The resulting model indicated that the poverty among food crops farmers had a positive correlation with road system (asphalt/concrete road) and location in upland area (mountain top/slope). When the other variables are constant, the poverty increases by 0.150 percent and 0.324 percent due to the increase in the number of villages with good road system and the increase in the number of villages in upland area by the factor of 1 , respectively. On the contrary, the amount of rainfall had a negative correlation to the number of poverty. The number of poverty decreases by 3.062 percent when the amount of rainfall increases by the factor of 1 , assuming that other variables are constant. However, the significant effect $(\mathrm{p}=0.05)$ of variables on poverty was only observed for road system and location in upland area. Furthermore, the coefficient of determination (R2) of 21.55 percent provided an indication that the poverty cases in Jambi Province could not be explained only using the global regression model and/or the three variables currently included for poverty analysis. Further residual analysis using the Kolmogorov Smirnov, Durbin Watson test and the Glejser method showed that the assumption of normal distribution and the assumption on similarity of poverty causal in all sub-districts were not met. Therefore, the use of spatial modeling approach for poverty analysis in Jambi province, such as Geographically Weighted Regression, is considered. Before the spatial analysis approach was applied, the dependency analysis using Moran test and Local Indicator of Spatial Autocorrelation (LISA) and spatial heterogeneity using the Breusch-Pagan test were used to observe the spatial effect on the poverty among food crops farmers. The analysis results are shown in Table 3 and Figure 4 .

Moran index and $\mathrm{p}$ value were used to describe the spatial dependency. The null hypothesis (H0:I=0) means that there is no spatial autocorrelation among the sub-districts, while the alternative hypothesis $\left(\mathrm{H}_{1}: \mathrm{I} \# 0\right)$ means that the spatial autocorrelation among the sub-districts was observed. Based on Moran's I analysis, autocorrelation among sub-districts was found for the variables of location in upland area, rainfall and poverty among food crops farmers $(p<0.05)$. The spatial dependency for poverty variable indicated that the poverty among the sub-districts was correlated, especially for those in neighboring area.

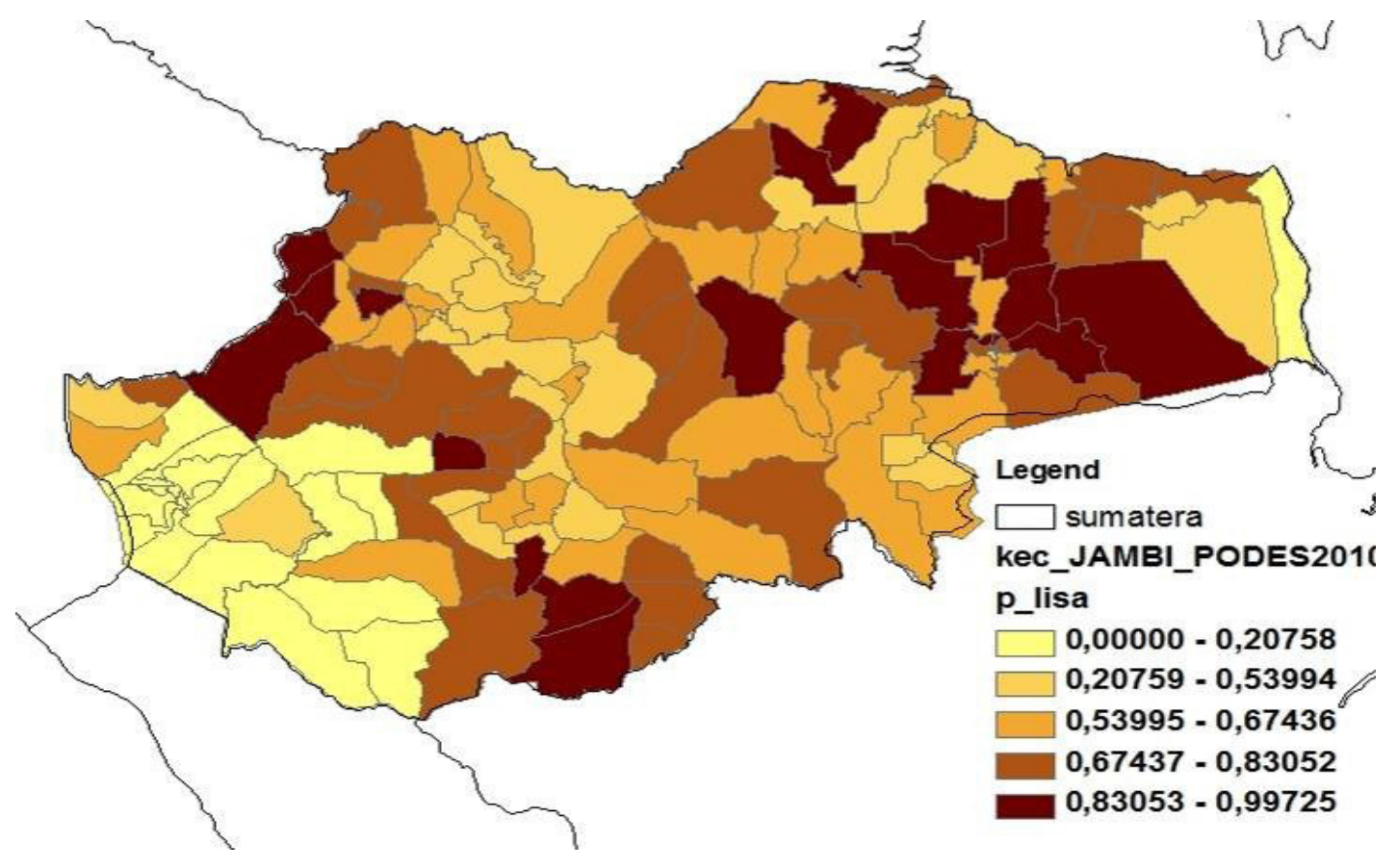

Figure 4. The p value of LISA in Each Sub District for Poverty among Food Crops Farmers 
Table 4. Parameter Estimates of GWR

\begin{tabular}{l|l|l|l|}
\hline \multicolumn{1}{c|}{ Variables } & \multicolumn{1}{c|}{ Minimum } & \multicolumn{1}{c|}{ Median } & Maximum \\
\hline Constant & -11.960 & -1.986 & 29.150 \\
Road system of asphalt/concrete & -0.131 & 0.080 & 0.708 \\
Location in upland area (mountain top/slope) & -1.026 & 0.049 & 0.838 \\
Rainfall & -6.886 & 1.101 & 6.270 \\
\hline
\end{tabular}

Table 5. The Comparison of GWR and Global Regression Model

\begin{tabular}{|c|c|c|c|c|}
\hline \multirow{2}{*}{$\frac{\text { OLS Model }}{\text { Variables }}$} & \multicolumn{4}{|c|}{ GWR model } \\
\hline & Min. & Max. & Mean & Std Dev. \\
\hline Intercept & 13.560 & -11.960 & 29.150 & 1.914 \\
\hline $\begin{array}{r}\text { Road system (asphalt/con- } \\
\text { crete) }(\mathrm{X} 1)^{*}\end{array}$ & 0.150 & -0.131 & 0.708 & 0.149 \\
\hline $\begin{array}{r}\text { Location in upland area } \\
\text { (mountain top/slope) }(\mathrm{X} 2)^{*}\end{array}$ & 0.324 & -1.026 & 0.838 & 0.014 \\
\hline Rainfall (X3) & -3.062 & -6.886 & 6.270 & 1.228 \\
\hline Diagnostic & & & & \\
\hline $\mathrm{R} 2$ & $21.55 \%$ & & & $55.84 \%$ \\
\hline Adjusted R2 & $19.69 \%$ & & & \\
\hline $\mathrm{AIC} / \mathrm{AICc}$ & 1091.65 & & & $1023.65 / 1049.243$ \\
\hline Number of parameters & 4 & & & 524 \\
\hline $\operatorname{Sigma}(\sigma)$ & 15.26 & & & 12.37 \\
\hline Residual sum of square & 29560.1 & & & 16638.58 \\
\hline
\end{tabular}

The sub-districts having high number of poverty rate are close to each other, and therefore form a cluster (Figure 2), as also indicated by Moran Index of 0.457 . Furthermore, thespatialdependencyanalysisusingLocal Indicator of Spatial Autocorrelation (LISA) identifies the local spatial autocorrelation or the spatial effect for each sub-district about poverty among food crops farmers. Stronger correlation among sub-districts is indicated by the low value of $\mathrm{p}$. The $\mathrm{p}$ value in the western-southern parts of Jambi province, around Kerinci and Merangin Regencies, was lower than that in other regencies, indicating the poverty correlation among the subdistricts in Kerinci and Merangin Regencies (Figure 4). The spatial heterogeneity analysis was used to determine the spatial effect and the characteristic heterogeneity among sub-districts. Using the BreuschPagan test, spatial heterogeneity was found when the global regression model (Equation 1 and Table 2) was used. Also, test of the residual assumption found the residual heterogeneity. Because spatial dependency and heterogeneity effects were reported from those analyses, the use of Geographically Weighted Regression (GWR) model in equation 2 is recommended. The result of the GWR model is presented in Table 4. This model used a fixed kernel bi-square for weighting process and a bandwidth value of 0.4275 . The bandwidth value of 0.4275 indicated that a sub-district will have a strong correlation with the other sub-districts in the radius of 0.42750 or $47.59 \mathrm{~km}$. The estimated parameters of GWR model for each sub-district are shown in Figure 5. The regression coefficient parameter of road system can have a positive or negative value, meaning that the road system has positive or negative impact on the poverty rate (Figure $5 \mathrm{a}$ ). The western-southern part of Jambi province had a high positive parameter estimate. This high positive value suggested that the more villages have a good road system, the higher the poverty rate is in that area. On the contrary, the increase in the number of villages with good road system contributed to the decrease in poverty rate in eastern part of Jambi. Similarly to the road system, location in upland area and the amount of rainfall also contributed to the positive and negative effects on the poverty rate.

Most of the western-southern of Jambi province, which is located in the upland area, have positive parameters value, meaning that the poverty is higher when more villages in the sub-districts are located in upland area. The effort to open a new potential and productive area is hindered by the lack of connection to the interregional road. The challenge to open the 


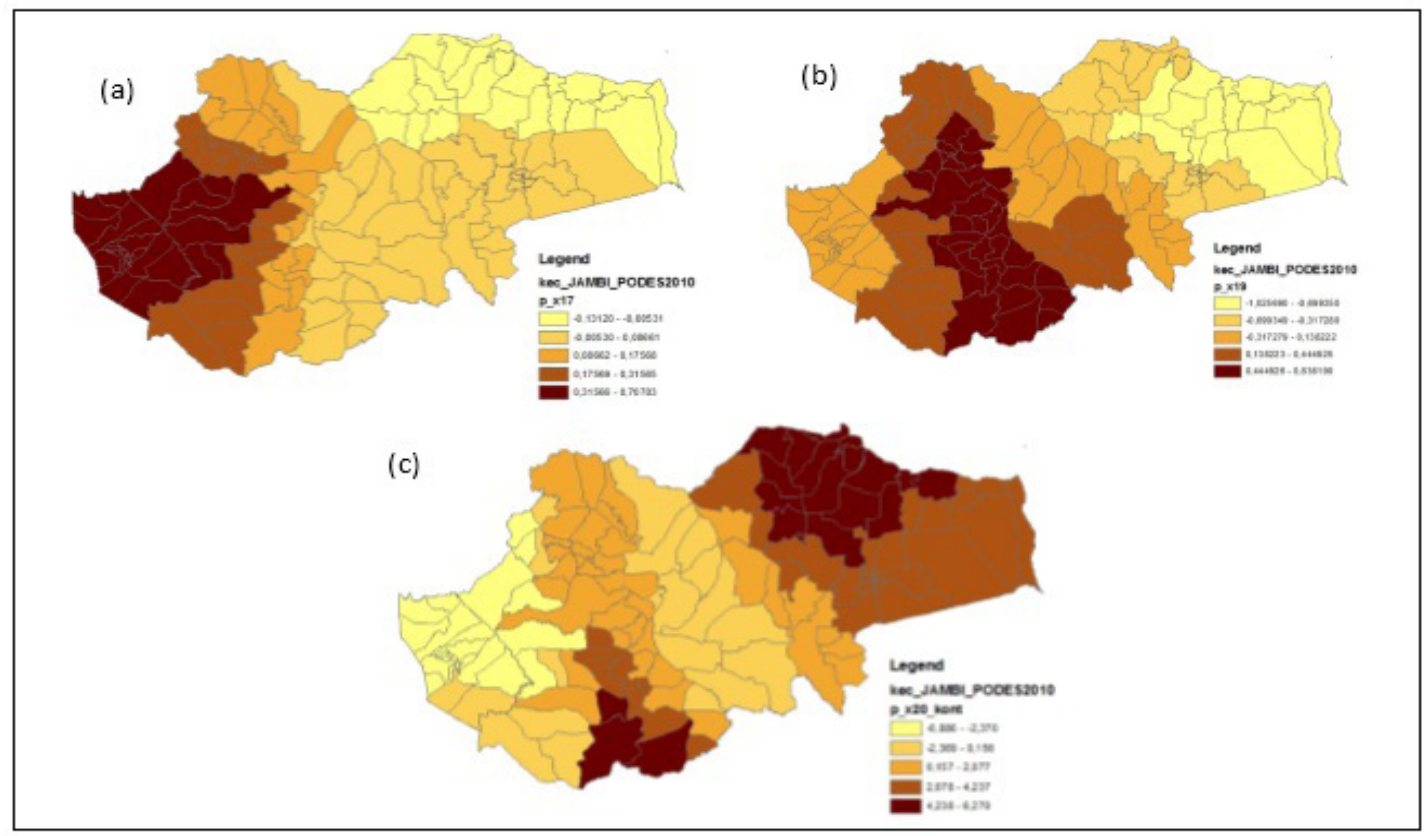

Figure 5.Parameter Estimates of GWR model: (a) road system, (b) upland area, (c) rainfall

connection is not only due to the budget availability, but also due to the difficult location, which influence the implementation of infrastructure program and its maintenance. Moreover, although the upland area has suitable climate and sufficient natural resources for agriculture production, it is not suitable for food crops production and is prone to landslide and volcanic eruption. Different situation was observed for the subdistricts in the eastern part of Jambi, which is much closer to the city center than the western-southern part of Jambi. In this area, the potency for food crops production is high and most of the inhabitants work as farmer. The variable of location in upland area was not significantly influence the poverty in this area, because most of the area was dominated by lowland agriculture area with irrigation system. It is then not surprising when the percentage of poverty in this area was a bit smaller than in western-southern part of Jambi. The amount of rainfall had different impact in different sub-districts. The variable of rainfall had a negative effect in the western-southern part of Jambi province and a positive impact in the central to eastern part of Jambi. Having a negative effect means that the area with high rainfall will have a lower percentage of poverty, whereas the positive value indicate that the higher amount of rainfall will contribute to the higher percentage of poverty in Jambi. This is because the high rainfall can lead to floods damaging crops. As in the Kerinci, Merangin, Muaro Jambi and Jambi City experienced frequent flooding result in reduced production of rice. Similar situation was also observed in Vietnam, when higher rainfall contributed to the decrease in poverty in some areas, but increased the poverty in the other areas [Minot et al., 2006]. However, the effect of rainfall on poverty in Jambi was only significant for fewer numbers of sub-districts. The $p$ values of each variable from the GWR model are presented in Figure 6. The variables of road system, location in upland area and the amount of rainfall have more influence in a sub-district with low $\mathrm{p}$ value than in sub-district with high $\mathrm{p}$ value. In general, the road system had high influence on poverty in the sub-districts of western and southern part of Jambi, while rainfall has significant effect on poverty for the sub-districts in the eastern part of Jambi.

Minot et al. [2006] reported that the occurrence of poverty was mostly spatially concentrated and in the remote area, which is far from the center of growth, has poor access and unfortunate geographical location. Kam et al. [2005] research in Bangladesh shows that the pockets of high poverty incidence generally coincide with the ecologically poor areas and poverty are low in area with high access such as livestock ownership, educational attainment and prevalence of clayey soils are high. Thongdora [2012] state that poverty has a spatial dimension in Nigeria. It shows that there was a poverty gap, specifically in rural area which depend on agricultural activitiesfor their livelihood. The majority of the rural poor are farm owners, farm workers and landless farmers. Similarly, the poverty in Jambi province was found in the area, which was far from the capital of Jambi province. Kerinci and Merangin regencies, which have high percentage of poverty, are located about $419 \mathrm{~km}$ and $255 \mathrm{~km}$, respectively, from the capital of Jambi. In this area, the parameter estimates of road system were mostly having a positive value, meaning that the more villages having good road system, the more number of poverty was reported. Unfortunately, the result did not correspond to the theory/hypothesis that the more villages having 


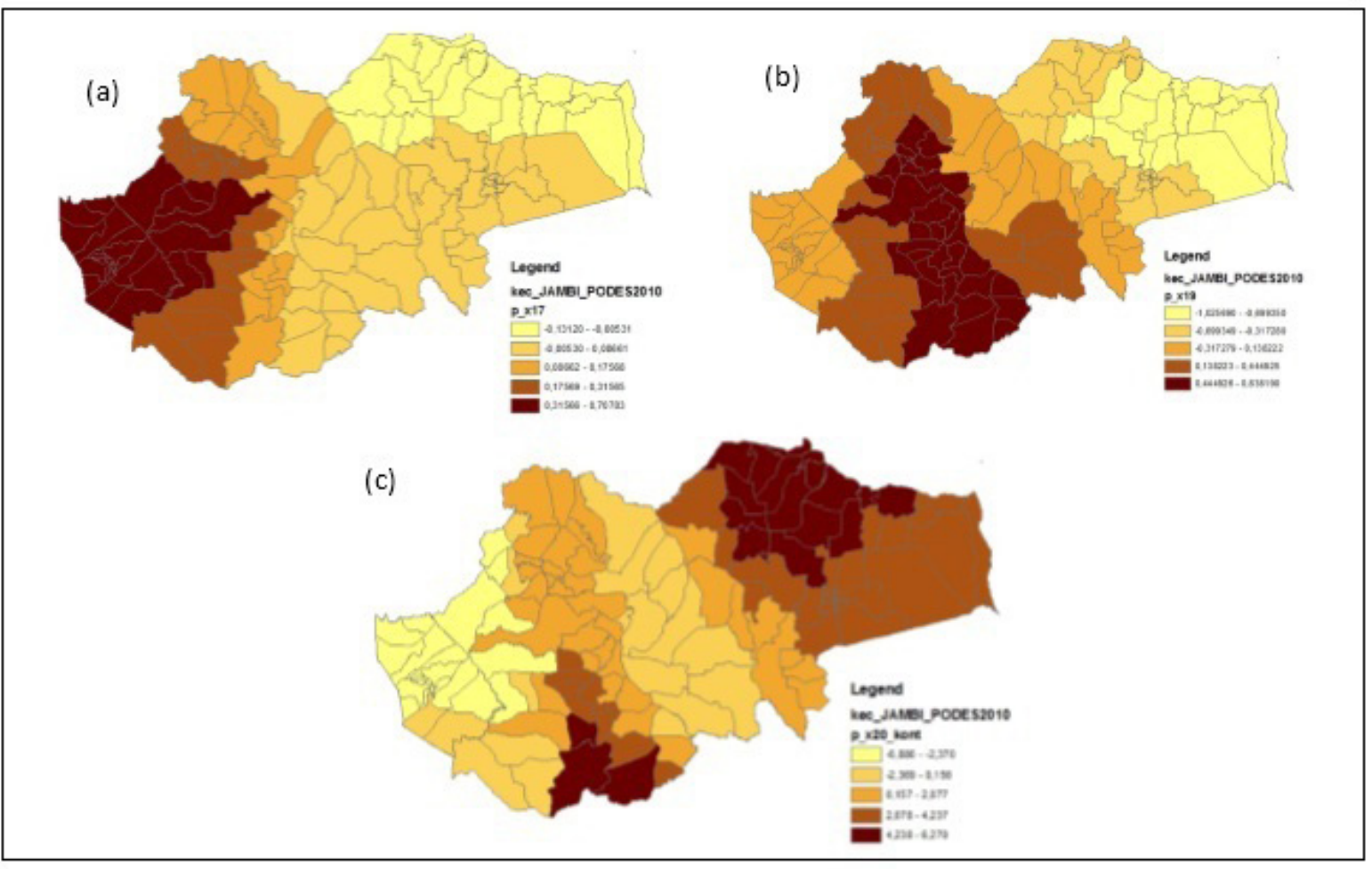

Figure 6.The p value of each variable in GWR model: (a) road system, (b) upland area, (c) rain fall

a good road system, the less number of poverty will be found. Although the road system between the center of production and the center of growth in that area was good, the interregional road system might not be sufficient and was far from the capital center. This poor access might be the reason for farmer's difficulty to sell their crops and to obtain the production input, increasing the number of poor people in the area with a good local road system. Furthermore, the concentrated economic activity might not be able to reduce the poverty rate in those areas. Because the commodity price was lower than the consumer price, farmer's income was lower than their expenditure. Consequently, the farmer exchange value (NTP) was lower, causing the increase in the number of poverty. In this case, the center of economic in such area failed to contribute to the positive spillover impact (spread effect) to its hinterland.

Based on the global regression analysis, variables affecting the poverty among food crops farmers were road system (asphalt/concrete road) and location in upland area. The global regression model, however, assumed that the parameter in all locations were similar and significant. This assumption was different from the observed characteristic since road system, location in upland area and the amount of rainfall had different influence on poverty rate in each location. Therefore, the global regression model was less suitable for the poverty analysis, which was location dependent. Alternatively, the GWR model, which considered the spatial effect, was be used for the poverty analysis for Jambi province. This conclusion was supported among others by the low value of the coefficient determination (R2) and higher AIC and Mean Square Error (MSE) as compared to GWR model (Table 5). The GWR analysis became more important considering also the dependency analysis and spatial heterogeneity. The result that GWR analysis was better than global regression model for poverty analysis in Jambi province confirm the previously described theory that spatial analysis should be used, instead of global regression model, for poverty analysis when spatial heterogeneity is observed. The better performance of GWR model over a more global model was also reported by Kam et al. (2005), Ali et al. [2007], Deller [2010], and Ali Thongdara et al. [2012].

\section{Conclusion}

A suitable poverty analysis model is needed to support the formulation of an effective policy for poverty reduction. Unfortunately, the global regression model, which has been widely used in Indonesia, is not suitable to analyze poverty in Jambi province due to the spatial difference. The use of GWR is more suitable for poverty analysis than the global regression model, indicated by the lower MSE and AIC value of GWR than the global regression model. Leung test also conclude that GWR model is better than global model. The effect of three variables: road system, location in upland area and the amount of rainfall on poverty is not generic. The presence of a good road system was not always related to the decrease in the number of poverty. When a good road system was observed, but the road was used for other purposes than agriculture, the number 
of poverty the area might also be high. Similarly, when the area was in lowland area, but the poverty is high, the area was probably located far from the center of growth, preventing fast access of agricultural product to the central market. However, those three variables were only able to explain around $50 \%$ of the poverty occurrence in Jambi sub district. Therefore, analysis which included other variables might be of interest.

\section{Acknowledgement}

Thank you for Ministry of Agriculture which has funded this reseach through the scholarship program.

\section{References}

ADB (2009). Kesejahteraan Petani dan Pengentasan Kemiskinan [internet]. [diacu 2015 Oktober 24]. http://www.mediaindonesia.com/mipagi/ read/ 16521 / Kesejahteraan - Petani - d a n Pengentasan-Kemiskinan (in bahasa indonesia).

Anselin, L. (2013). Spatial econometrics: methods and models (Vol. 4). Springer Science \& Business Media.

Ali, K., Partridge, M. D., \& Olfert, M. R. (2007). Can geographically weighted regressions improve regional analysis and policy making?. International Regional Science Review, 30(3), 300-329.

Badan Pusat Statistik (2013). Laporan Hasil Sensus Pertanian 2013 (Pencacahan Lengkap), BPS Provinsi Jambi, Jakarta. (in bahasa Indonesia).

Badan Pusat Statistik (2014). Analisis Sosial Ekonomi Petani di Indonesia. Hasil Survei Pendapatan Rumah Tangga Usaha Pertanian. Sensus Pertanian 2013, BPS, Jakarta.

Badan Pusat Statistik (2015). Statistik Potensi Desa Provinsi Jambi 2014, BPS, Jambi. (in bahasa Indonesia).

Badan Pusat Statistik (2015). Indeks Harga yang Diterima Petani (It), Indeks Harga yang Dibayar Petani (Ib), dan Nilai Tukar Petani (NTP) Menurut Provinsi, 2008-2014 [internet]. [diacu 2015 Mei 25]. Tersedia di http://bps. go.id/linkTabelStatis/view/id/1482.(in bahasa Indonesia).

Badan Pusat Statistik (2016). Profil Kemiskinan Indonesia September 2015, BPS, Jakarta.(in bahasa Indonesia).

Bekti, R.D., andSutikno (2012).Spatialdurbin model toidentify influential factors of diarrhea. J. Math. Statistics, 8:396-402

Brunsdon, C., Fotheringham, A. S., \& Charlton, M. (2002). Geographically weighted summary statistics-a framework for localised exploratory data analysis. Computers, Environment and Urban Systems, 26(6), 501-524.

Cappelo, R (2009). Spatial Spillover and Regional Growth : a Cognitive Approach. European Planning Studies, 17(5)

Fischer, M.M., and Getis, A (2010). Handbook of Applied Spatial Analysis, Software Tools, Methods and Applications, Springer, New York.

Fotheringham, A. S., Charlton, M. E., \& Brunsdon, C. (1998). Geographically weighted regression: a natural evolution of the expansion method for spatial data analysis. Environment and planning A, 30(11), 1905-1927.

Gujarati, D.N (2010). Basic Econometrics. Mc Graw-hill Companies, New York.

Hill, R. C., Griffiths, W. E., and Lim, G. C (2011). Principles of econometrics, John Wiley \& Sons, Inc, USA.

Jajang (2014). Modifikasi Statistik Getis Lokal pada MatriksPembobot AMOEBA untuk Model Panel Spasial dan Kajian Performanya. Sekolah Pascasarjana IPB, Bogor.
Kam, S. P., Hossain, M., Bose, M. L., \& Villano, L. S. (2005). Spatial patterns of rural poverty and their relationship with welfare-influencing factors in Bangladesh. Food Policy, 30(5), 551-567. Lisanty, N., \& Tokuda, H. (2015). Comprehending Poverty in Rural Indonesia: An In-depth Look inside Paddy Farmer Household in Marginal Land Area of Banyuasin District, South Sumatra Province. International Journal of Social Science Studies, 3(3), 129-137.

Minot, N., Baulch, B., \& Epprecht, M. (2006). Poverty and inequality in Vietnam: Spatial patterns and geographic determinants (p. 148). Washington, DC: International Food Policy Research Institute.

Muta'ali (2012). Daya Dukung Lingkungan Untuk Perencanaan Pengembangan Wilayah. Badan Penerbit Fakultas Geografi, Universitas Gadjah Mada

Pasaribu, E (2015). Dampak Spillover dan Multipolaritas Pengembangan Wilayah Pusat-Pusat Pertumbuhan di Kalimantan. Sekolah Pascasarjana. IPB.

Saefuddin, A., Setiabudi, N. A., \& Achsani, N. A. (2011). On comparison between ordinary linear regression and geographically weighted regression: With application to Indonesian poverty data. European Journal of Scientific Research, 57(2), 275-285.

Saefuddin, A., Setiabudi, N. A., \& Fitrianto, A. (2012). On comparison between logistic regression and geographically weighted logistic regression: With application to Indonesian poverty data. World Applied Sciences Journal, 19(2), 205-210.

Smajgl, A., \& Bohensky,E. (2013). Behaviour and spacein agentbased modelling: poverty patterns in East Kalimantan, Indonesia. Environmental modelling \& software, 45, 8-14.

Sudarlan, R.I., and Yusuf, AA (2015). Impact Of Mining Sector To Poverty And Income Inequality In Indonesia: A Panel Data Analysis, International Journal Of Scientific \& Technology Research, 4 (06) : 195-200. Sudaryanto, T., Susilowati, S. H., \& Sumaryanto, S. (2009). Increasing Number of Small Farms in Indonesia: Causes and Consequences. In European Association of Agricultural Economists, 111th Seminar. Sumarto, S, and de Silva, I (2013). Poverty-growthInequality Triangle: The Case of Indonesia (No. 57135), University Library of Munich, Germany. Suryahadi, A., \& Hadiwidjaja, G. (2011). The role of agriculture in poverty reduction in Indonesia. Jakarta: SMERU Research Institute. Teguh, D., \& Nurkholis, N. (2011). Finding out of the Determinants of Poverty Dynamics in Indonesia: Evidence from Panel Data (No. 41185). University Library Thongdara, R., Samarakoon, L., Shrestha, R. P., \& Ranamukhaarachchi, S. L. (2012). Using GIS and spatial statistics to target poverty and improve poverty alleviation programs: A case study in northeast Thailand. Applied Spatial Analysis and Policy, 5(2), 157-182. Warr, P (2013). Food Security, Agriculture, and Poverty in Asia. World Bank (2007). Era Baru Dalam Pengentasan Kemiskinan di Indonesia. Indopov. The World Bank. Jakarta

Yamauchi, F., and Muto, M. S, Chowdhury, R. Dewina, and S. Sumaryanto (2010). Are Schooling and Roads Complementary? Evidence from Rural Indonesia. JICA Research Institute Working Paper, 10

Yosnofrizal (2015). Petani dan Jerat Kemiskinan [internet]. [diacu 2015 September 25]. Tersedia di http://www.harianhaluan.com/index.php/ opini/ 9375 - petani-dan-jerat-kemiskinan 